\title{
Ecofriendly Solar Bicycle
}

\author{
${ }^{1}$ Pooja Niwalkar, ${ }^{\square}{ }^{2}$ Smita Daware,${ }^{3}$ Prachi Rane, ${ }^{4}$ Prachi Gujarati, ${ }^{5}$ Nidhi Lakhanpal \\ 1,2,3,4,5 Department of Electronics Engineering, Shri Ramdeobaba College of Engineering and Management, Nagpur, \\ India. \\ niwalkarpm@rknec.edu,dawaresg@rknec.edu,ranepp1@rknec.edu,gujaratipm@rknec.edu, \\ lakhanpaln@rknec.edu
}

Received: 10th July 2020, Accepted: 27th July 2020, Published: 31st August 2020

\begin{abstract}
Modern technology has enabled us to capture the ills of pollution including its growth at an alarming level. In the early part of 2020 the global shutdown due to Covid-19 caused the environment to 'Reset' itself by cleaning it's rivers, oceans and skies. Clean energy helps to maintain a clean environment. We are introducing an ecofriendly solar bicycle which will support a pollution free environment. In addition, it will also support the good health of the rider as bicycle riding will engage a lot more balance and coordination than riding a car. It is pocket friendly and convenient way to travel short distance. Assembly consist of BLDC motor, Solar panel, Boost converter, Lead Acid Battery, Motor controller, throttle which works as an accelerator and a battery indicator. The solar panel is used to charge the lead acid battery through boost converter, which drives the BLDC motor connected to Pedal pass. While cycling if pedal is used, motor consumes less power and so the distance travelled will be doubled. To enhance the visual experience of user, Battery indicator is provided to monitor the battery status. The Motor controller acts as a brain of the bicycle. It orchestrates every component in the bicycle. During Cloudy Weather conditions USB charger can be utilized as an alternative to charge the battery.
\end{abstract}

\section{Keywords}

BLDC Motor, Motor Controller, Solar Panel, Battery, Throttle.

\section{Introduction}

In present scenario a Solar Bicycle system will help to solve the major problems of fuel and pollution. There is no doubt that the emission of carbon-dioxide from an automobile exhaust is a concern for the increasing rate of global warming. The fuel prices in India and around the world is increasing day by day thus there is a tremendous need to search for an alternative to conserve these natural resources. Promoting use of solar vehicles can reduce $\mathrm{CO}_{2}$ emission and the fuel costs. Thus a solar bicycle is an electric vehicle which provides alternative by utilizing solar energy to charge the battery and thus provide required voltage to run the motor. Bicycle combines the use of solar energy as well as the dynamo that runs through pedal to charge the battery to run the bicycle. The bicycle has the most feasible solar/electric power generation system mounted on the vehicle to charge the battery during all the time. This multi charging vehicle can charge itself from both solar and mechanical power. Solar panels can be mounted on the backside of bicycle to capture the sun rays. When there is no presence of sun, mechanical work act as an auxiliary energy source. For controlling speed of the motor, an accelerator is given which controls the supply. This type of technique is to reduce the running cost and increasing the running efficiency of the vehicle

A solar bicycle is electric vehicle which needs less energy as compared to standard conventional vehicle. Standard electric vehicle requires plug in electricity to charge their in build power modules. Solar bicycle is more cost efficient and light-weight as compared to conventional vehicle. It has a rechargeable battery which can travel up to $25-30 \mathrm{~km}$. Alternative energy is employed to charge the batteries with the help of auxiliary power which may take use of USB charger or phone charger. It has low maintenance cost. Battery gives required voltage to the BLDC hub motor which is connected to the rim of the bicycle. E-bikes need large and heavy batteries to permit riding long distances, because the battery is charged just once at reception as compare to solar bicycle, its approach is optimal. The electrical device has enough power and provides the bicycle to achieve remarkable extended power range. The main benefit of bicycle is battery gets enough charge during its running. Solar bicycle is developed to condense the pollution caused by conventional vehicles. 


\section{Components}

\section{A. Solar Panel}

Table 1: Solar Panel Specifications

\begin{tabular}{|l|l|}
\hline Parameter & Value \\
\hline Maximum Power Rate(Watt) & $50 \mathrm{~W}$ \\
\hline Maximum Power Voltage & $17.56 \mathrm{~V}$ \\
\hline Open Circuit Voltage(Voc) & $21.6 \mathrm{~V}$ \\
\hline Maximum Power Current (Imp) & $2.85 \mathrm{~A}$ \\
\hline Short Circuit Current (Isc) & $3.30 \mathrm{~A}$ \\
\hline Cell Efficiency & $14.02 \%$ \\
\hline Solar Cell & 36 Cells \\
\hline Dimension & $850 \times 541 \times 30 \mathrm{~mm}$ \\
\hline Weight & $6.1 \mathrm{~kg}$ \\
\hline
\end{tabular}

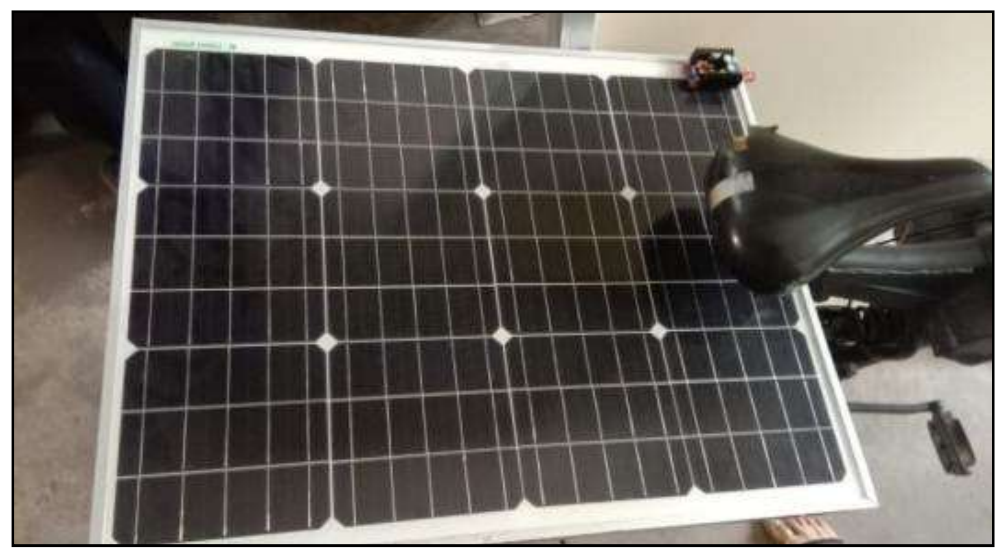

Figure 1: Solar Panel

The term solar panel refers to a photovoltaic module which is a packed assembly of photovoltaic cells, called as solar cells. Solar cell is typically made from Silicon, which is a semiconductor and generates electricity. This process is known as Photovoltaic effect. As the title suggest the bicycle is operated by solar energy. Solar cells convert the energy from the sun directly into electricity based on photovoltaic effect. Photovoltaic cells absorb the sun's energy and convert it to DC electricity [1].Table no. 1 depicts the specifications of solar panel.

\section{B. Boost Converter}

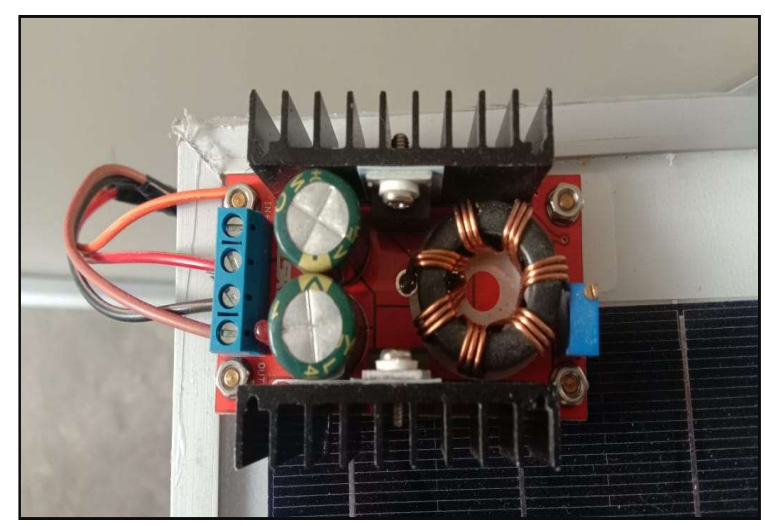

Figure 2: Boost Converter

The output power of the solar panel is not always constant and such a system cannot be connected to battery directly. To provide constant input to the battery, a boost converter module which works a voltage regulator is shown in figure no. 2. In order to maintain a constant voltage and optimal performance a voltage regulator is used. Voltage regulator also extends the lifespan of the equipment as there will be no component failure due to voltage fluctuations. It is used to protect the system from over and under voltages. [3]

Output voltage from solar panel (Vout) $=12 \mathrm{~V}$ 
Required voltage by the battery $($ Vin $)=36 \mathrm{~V}$

Vout $=$ Vin $/(1-D), D=2 / 3$

\section{Lead Acid Battery}

Table 2: Lead Acid Battery Specifications

\begin{tabular}{|l|l|}
\hline Parameter & Corresponding factor/value \\
\hline Type & Lead Acid \\
\hline Number & 3 \\
\hline Voltage & $12 \mathrm{~V}$ \\
\hline Connected & In series \\
\hline
\end{tabular}

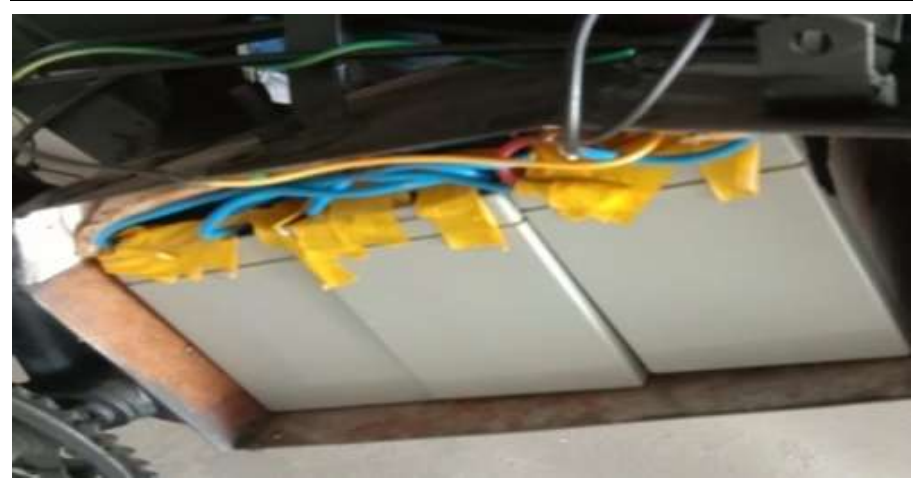

Figure 3: Lead Acid Battery

Lead Acid batteries are cheapest and safe to use. Battery is a series arrangement of cells (Fig No. 3) that generate electricity by a process of Electro-chemical reaction. The output power from voltage regulator module is stored in batteries. Lead is a chemical element $(\mathrm{Pb})$, it can donate a proton or accept an electron pair when it is reacting, and it consists of Lead and anhydrous plumbic acid. [4]. Table no. 2 shows the specifications of battery used. Output of battery unit is $36 \mathrm{~V} \mathrm{DC}$.

\section{Motor Controller}

Table 3: Motor Controller Specifications

\begin{tabular}{|l|c|}
\hline \multicolumn{1}{|c|}{ Parameter } & Value \\
\hline System voltage $(\mathrm{V})$ & $36 \mathrm{~V}$ \\
\hline Rated current $(\mathrm{A})$ & 27 \\
\hline Under voltage protection $(\mathrm{V})$ & 27 \\
\hline Ambient temperature $\left({ }^{\circ} \mathrm{C}\right)$ & $0-50$ \\
\hline
\end{tabular}

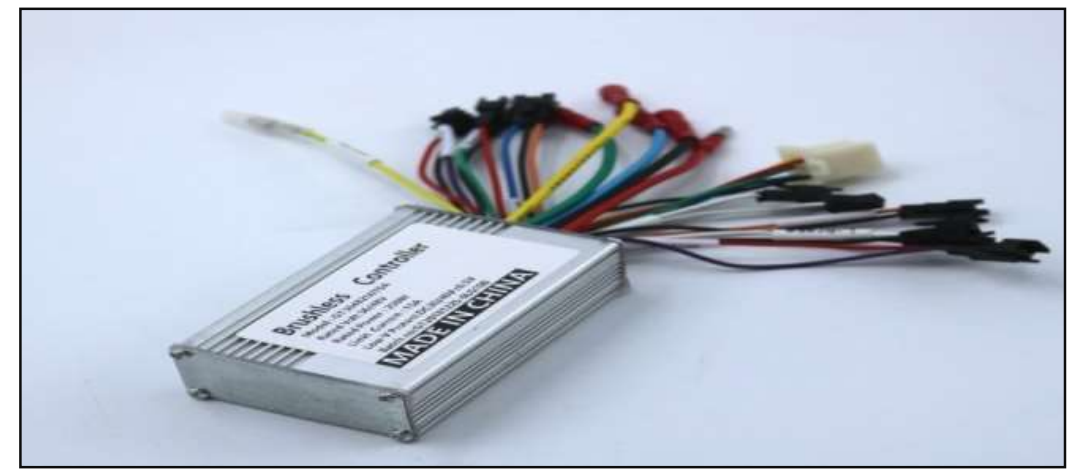

Figure 4: Motor Controller

The motor controller is a very essential component for the continuous operation of a brushless DC motor. The motor controller consists of the Hall Effect sensors that senses the north and south poles of the magnet in the motor and gives instruction to excite the required coils. The motor controller consists of MOSFETS, transistors and microprocessors. A motor controller operates in automatic mode for starting and stopping the motor, selecting and regulating the speed, regulating or limiting the torque, and protecting against overloads and electrical faults [3]. Specification of motor controller are specified in Table no.3 


\section{E. Hub Motor}

Table 4: HUB Motor specifications

\begin{tabular}{|c|c|}
\hline Parameter & Corresponding values \\
\hline Type of Motor & Hub motor \\
\hline Design of motor & BLDC (Brushless DC) \\
\hline Power Rating & $250 \mathrm{Watt}$ \\
\hline Rated Voltage(V) & $36 \mathrm{~V}$ \\
\hline Efficiency $(\%)$ & $80 \%$ \\
\hline Torque(N-M) & 14 \\
\hline Speed(RPM) & $300-400$ \\
\hline
\end{tabular}

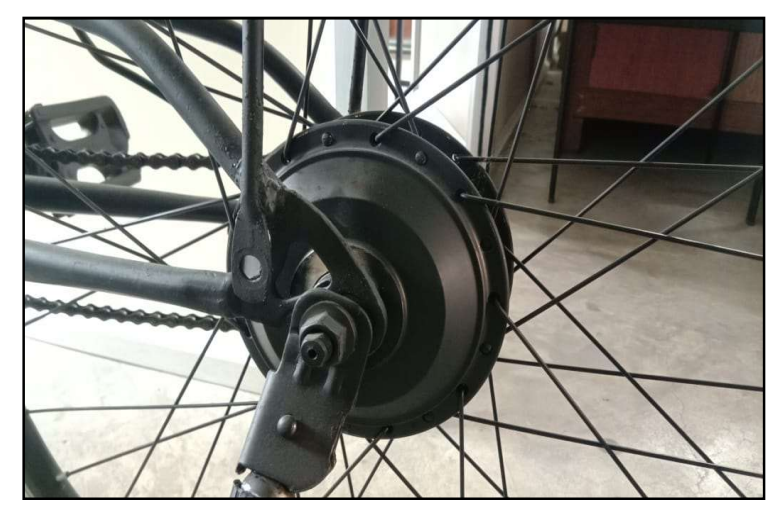

Figure 5: HUB Motor

A conventional brushless BLDC hub motor is used. Brushes are avoided to reduce maintenance, saving cost and time. It is more efficient than normal DC motors. The inner part having the coils is stationary and the magnet rotates around the coil. HUB Motor generates high torque at low speed. The electronic circuit present in the motor induces power in the inner copper coils makes the outer body spins around the copper coils. There are Hall-effect sensors attached between the coils. When the outer permanent magnet passes through the sensors, the sensors senses the position of the north and south poles of the rotor and then activates the required coils for continuous rotation [2]. Table no.4 depicts the specification of Hub motor.

\section{F. Accelerator \& Battery Indicator}

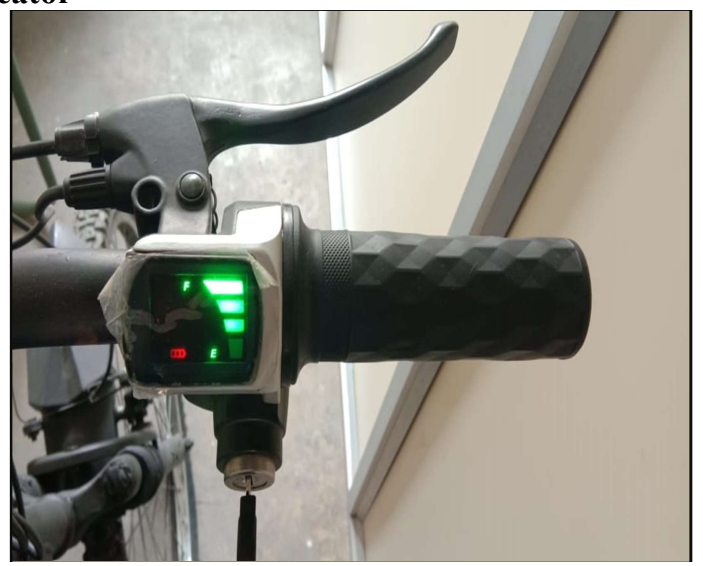

Figure 6: Accelerator and Battery Indicator

The maximum speed of the bicycle is $30 \mathrm{kmph}$. It varies the speed from $0-30 \mathrm{kmph}$ depending on the road conditions and traffic. The throttle which acts like an accelerator is connected to a motor controller. Voltage provided to the accelerator is $4 \mathrm{~V}$. The voltage is increased once throttle is activated. The battery indicator is used to indicate charge of the battery [3]. 


\section{G. Pedal Pass}

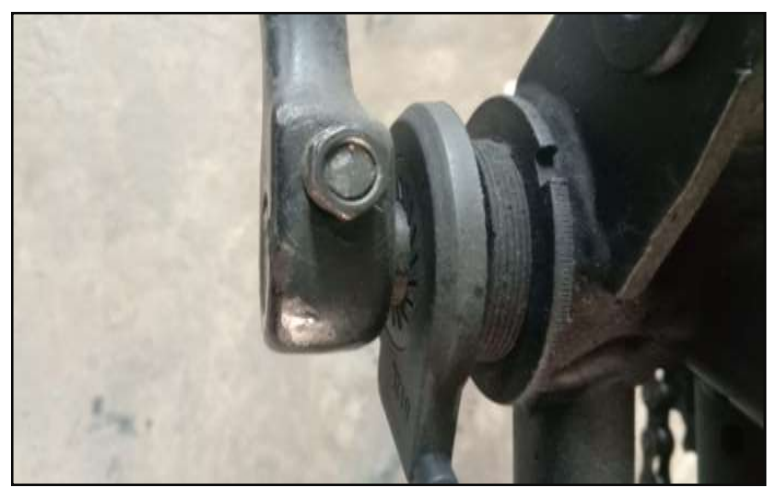

Figure 7: Pass

Pass is used to increase the average distance travelled by the bicycle with specified battery power. It generates the mechanical force to run the bicycle. This provides power only when pedaling is done. The faster the cadence of pedal, faster the motor will spin due to the controller. This boosts the acceleration of bicycle.

\section{Methodology}

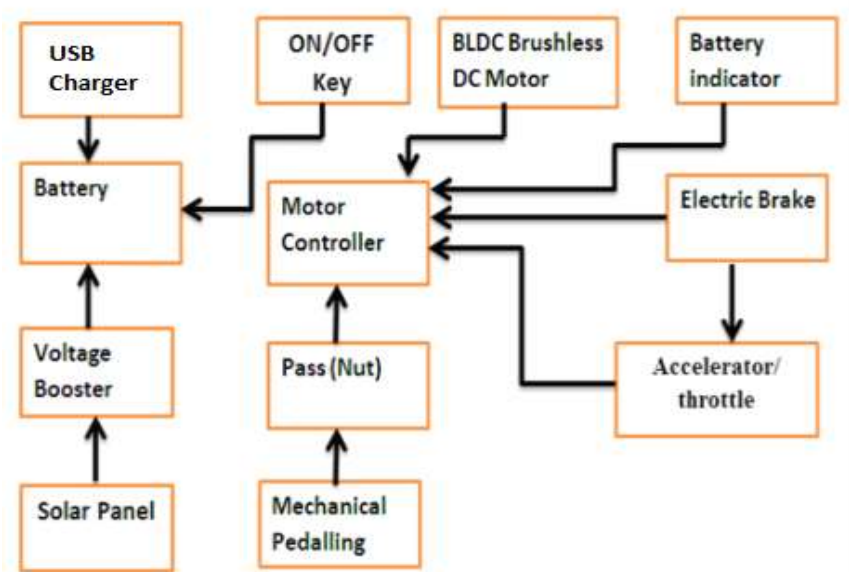

Figure 8: Block Diagram of Bicycle Model

\section{Working}

A Solar Panel is employed to capture the sun's energy, which gives 12V, 3.6A current and is not constant. Voltage regulator module is used to provide constant DC voltage and gives $36 \mathrm{~V}$ required for driving a BLDC motor. This energy is stored in the batteries which are connected in series and is capable to store the 36V. During cloudy weather or at night, it can be charged by external USB charger. A motor controller directs all functions in the bicycle. All components are connected to the motor controller except solar panel and boost converter. It acts as brain of the bicycle. It orchestrates every component to work properly. The motor rotates the wheels of the bicycle and controls the speed with help of the accelerator. In order to enhance the user experience, we have a well laid out visual panel indicating the batteries charge level at all times. When the bicycle is in running stage, and at the same time pedaling is done; pass connected to the pedal gives information to the motor controller and controller gives instruction to the motor. Motor uses less power and so the distance travelled by the bicycle in a single charge nearly doubles. When the bicycle is powered on, battery provides supply to the controller otherwise it functions as a normal bicycle.

\section{Factors Affecting Efficiency}

During cloudy weather or at night, there is less potential developed by solar panels; so there is a chance of reverse current flowing to the solar panel causing the battery to discharge, which is not optimal. To avoid the problem, there is a diode present in voltage booster which acts as one way medium from the panel to the battery. Solar panel is detachable, so it can be removed or fixed at any point of time. Power output of the solar panel depends on angle of placement. When solar panel is not facing towards the sun, power generated by the solar panel is very less than the rated amount and if it faces towards the sun it generates maximum power. 


\section{Factors below provide some variance in efficiency}

- Optimal Time of charge: The Maximum power generation is between 11:00AM-3:00PMafter that, less amount of sun rays is available.

- Reflection factor: If solar cell reflects high amount of light rays, power generation will be reduced. Hence a protective layer should be added on the top of the panel with a very low reflective coefficient.

- Weather: During cloudy weather, when there is very less amount of sunlight available, potential developed by solar panel is not sufficient to charge the battery. To compensate this, USB charger may be used.

- Shadow effect: If Solar panel is placed under the shaded area then it cannot produce large amount of energy. The Solar panel is always on the top of the bicycle, so that it will get maximum sunlight to generate maximum power so that the efficiency does not reduce.

- Load: Speed of the bicycle depends on the load mounted on it. If load on bicycle is limited then efficiency will be good. If load is increase beyond the particular limit then motor requires more power from batteries. By this efficiency of the bicycle may degrade.

\section{Result}

Table 5: Comparison Summary

\begin{tabular}{|l|l|l|l|}
\hline Parameters & Normal Bicycle & Existing solar bicycle & Ecofriendly Solar Bicycle \\
\hline Batteries & Not used & Li-ion & Lead acid \\
\hline Pass & Not Used & Not Used & Used \\
\hline Solar Panel(Watts) & Not Used & 100 Watt & 50 Watt \\
\hline Motor & No & Yes & Yes \\
\hline Electric Brakes & No & No & Yes \\
\hline $\begin{array}{l}\text { Battery Capacity(When } \\
\text { fully charged) }\end{array}$ & Not Used & $30 \mathrm{KM}$ & $30 \mathrm{KM}$ \\
\hline Cost(Rs.) & $6000 /-$ & $30,000 /-$ & $24,000 /-$ \\
\hline
\end{tabular}

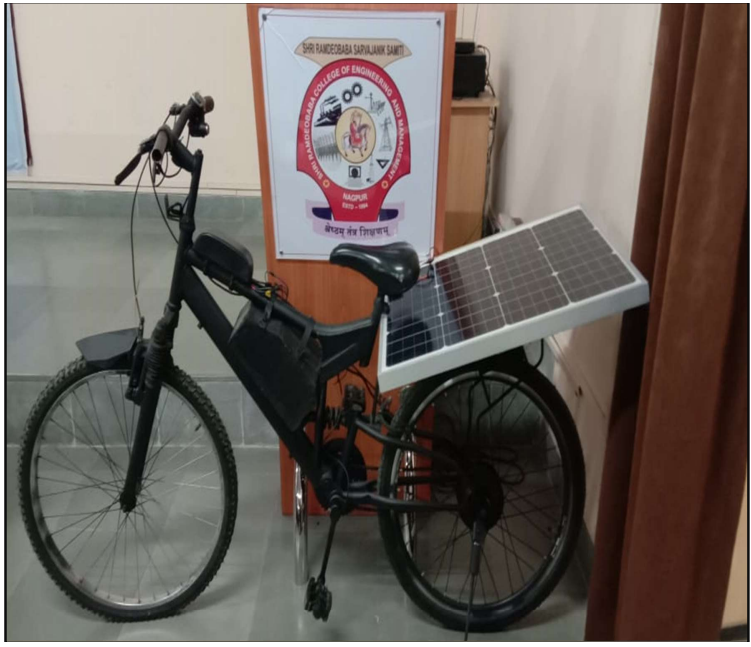

Figure 9: Solar Bicycle

\section{Conclusion}

The efficiency of the solar bicycle is $80 \%$. The maximum speed of the cycle is $28-30 \mathrm{Km} / \mathrm{hr}$. When battery gets fully charged, it can travel up to 30 to $35 \mathrm{~km}$. One can observe efficient performance of bicycle when the load is less than $110 \mathrm{~kg}$. This bicycle emphasize on the use of green energy to reduce the pollution. Solar bicycle is cost effective as compared to conventional bike. The total cost of this solar bicycle is Rs. 24,000/. This bicycle requires low maintenance; battery may be replaced due to wear and tear, over a period of time. The torque of 0.658 Newton meter is used to vary the speed. The charging time for bicycle by solar panel is $5 \mathrm{hrs}$ and by USB charger is $3.5 \mathrm{hrs}$. Rated 
speed of the bicycle is between 1800-3900 rpm. In future by using Super Capacitor weight of the bicycle may be reduced.

\section{References}

[1] Dr.Y.Sujatha, R. Jeelan, B. Ramakrishna "Solar Bicycle Performance and Analysis in Andhra Pradesh" IJRMET Vol-7, Issue 1, Nov 2016-April 2017.

[2] Shubham Nagwe, Tausif Shaikh, Vaibhav Sangale, Jagruti Sapkale, Ankita Singh " Solar E-Bicycle" IJARIIE ISSN(O)-2395-4396, Vol-5 Issue-1 2019.

[3] G.Srinivasa Rao, K. Harinadha Reddy, Raghu Thumu and ChAmarendra "Design of Solar Bicycle" Journal of Advanced Research in Dynamical and Control System Vol. 9. Sp- 6/ 2017.

[4] Kartik S Mishra, Shubham V Gadhawe, Dhiraj C Chaudhari, Bhupendra Varmaand S.B .Barve "Design And Development of Solar Hybrid bicycle" International Journal of Current Engineering and Technology,P-ISSN 23475161, Special issue-4, March 2016.

[5] C.Sivapragash ,C. Shankar, M. Nageena, B. Reetha Devi, K.Kiruthiga "An innovative solar powered electric bicycle” International Conference on Science, Technology, Engineering \& Management,,ICON-STEM’15,July 2015. [6] H.S. Upare, P.S Pandure "Design and Experimental study of Solar Hybrid Bicycle: A Review" IOSR Journal of Mechanical and Civil Engineering (IOSR-JMCE), e-ISSN: 2278-1684, P-ISSN: 2320-334x, pp44-48, March 2017.

[7] Sunilkshita Katoch, Rahul, Ranjit Kumar Bindal "Design and implementation of Smart Electric Bike EcoFriendly” International Journal of Innovative, IJITEE ISSN: 2278-3075, Volume-8, Issue-6S4, April 2019.

[8] ChetanMahadik, Sumit Mahindrakar, Prof. Jayashree Deka "An Improved \& Efficient Electric Bicycle system with the Power of Real-time Information Sharing" Multidisciplinary Journal of Research in Engineering and Technology, Volume 1, Issue 2, pp215-222, M15-1-2-7-2014. 